University of Nebraska - Lincoln

DigitalCommons@University of Nebraska - Lincoln

2003

\title{
Inhibition of Markers of Hepatic Stellate Cell Activation by the Hormone Relaxin
}

\author{
Robert G. Bennett \\ Department of Medical Research, Veterans Affairs Medical Center, 4101 Woolworth Ave., Omaha, NE \\ Kusum K. Kharbanda \\ University of Nebraska Medical Center, kkharbanda@unmc.edu \\ Dean J. Tuma \\ Department of Internal Medicine, University of Nebraska Medical Center, Omaha, NE, USA
}

Follow this and additional works at: https://digitalcommons.unl.edu/publichealthresources

Part of the Public Health Commons

Bennett, Robert G.; Kharbanda, Kusum K.; and Tuma, Dean J., "Inhibition of Markers of Hepatic Stellate Cell Activation by the Hormone Relaxin" (2003). Public Health Resources. 37.

https://digitalcommons.unl.edu/publichealthresources/37

This Article is brought to you for free and open access by the Public Health Resources at DigitalCommons@University of Nebraska - Lincoln. It has been accepted for inclusion in Public Health Resources by an authorized administrator of DigitalCommons@University of Nebraska - Lincoln. 


\title{
Inhibition of markers of hepatic stellate cell activation by the hormone relaxin
}

\author{
Robert G. Bennett ${ }^{\mathrm{a}, \mathrm{b},{ }^{*} \text {, Kusum K. Kharbanda }}{ }^{\mathrm{a}, \mathrm{b}}$, Dean J. Tuma ${ }^{\mathrm{a}, \mathrm{b}}$ \\ ${ }^{a}$ Department of Medical Research, Veterans Affairs Medical Center, 4101 Woolworth Ave., Omaha, NE 68105, USA \\ ${ }^{\mathrm{b}}$ Department of Internal Medicine, University of Nebraska Medical Center, Omaha, NE, USA
}

Received 9 January 2003; accepted 12 May 2003

\begin{abstract}
Hepatic fibrosis results from excess extracellular matrix produced primarily by hepatic stellate cells (HSC). In response to injury, HSC differentiate to a myofibroblastic phenotype expressing smooth muscle actin and fibrillar collagens. Relaxin is a polypeptide hormone shown to have antifibrotic effects in fibrosis models. In this study, activated HSC from rat liver were treated with relaxin to determine if relaxin can reverse markers of HSC activation. Relaxin treatment resulted in a decrease in the expression of smooth muscle actin, but had no effect on cell proliferation rate. The levels of total collagen and type I collagen were reduced, while the synthesis of new collagen was inhibited. Furthermore, relaxin caused an increase in the expression and secretion of rodent interstitial collagenase (MMP-13), but there was no effect on the gelatinases MMP-2 or MMP-9. Relaxin also increased secretion of TIMP-1 and TIMP-2. The effective concentration of relaxin to induce these effects was consistent with action through the relaxin receptor. In conclusion, relaxin reversed markers of the activated phenotype of HSC including the production of fibrillar collagen. At the same time, the activity of a fibrillar collagenase was increased. These data suggest that relaxin not only inhibits HSC properties that contribute to the progression of hepatic fibrosis, but also promotes the clearance of fibrillar collagen. Therefore, relaxin may be a useful approach in the treatment of hepatic fibrosis.
\end{abstract}

\section{Introduction}

The central event in the processes leading to liver fibrosis is the activation of HSC (see [1-3] for recent reviews). In the normal state HSC are quiescent cells that store lipid in the form of retinoids, and produce low amounts of ECM, mostly type IV collagen. Liver injury results in a change in HSC from a quiescent state to an "activated" myofibroblastic phenotype characterized by loss of retinoid stores, increased proliferation, contractility, and expression of $\alpha$ smooth muscle actin (SMA) [4,5]. In addition, reflecting the changes seen in fibrotic liver, the production of ECM components and their degrading enzymes also changes drastically. Normally, there is a highly regulated balance between production and degradation of ECM components

\footnotetext{
* Corresponding author. Tel.: +1-402-346-8800x3105; fax: +1-402-449-0604.

E-mail address: rgbennet@unmc.edu (R.G. Bennett).

Abbreviations: HSC, hepatic stellate cells; ECM, extracellular matrix; SMA, smooth muscle $\alpha$-actin; MMP, matrix metalloproteinase; TIMP, tissue inhibitor of metalloproteinases.
}

to maintain the extracellular architecture. After HSC activation, overall collagen levels increase greatly, with type I collagen as the predominant form [6]. There are also widespread changes in the matrix-degrading enzymes and their regulators. The expression of interstitial collagenases that degrade fibrillar collagen (MMP-1 and MMP-13) is reduced [7], while conversely, the activity of MMP-2 (gelatinase A) is upregulated $[8,9]$ resulting in increased degradation of nonfibrillar (types II and IV) collagens and decreased degradation of fibrillar (types I and III) collagens. At the same time, the expression of the tissue inhibitor of metalloproteinases (TIMP) is increased [10], further shifting the balance away from degradation and toward accumulation of collagen. Therefore, the reduction or reversal of HSC activation is an attractive therapeutic target in the treatment of hepatic fibrosis.

Relaxin is a member of the insulin family of polypeptide hormones (see [11,12] for review), although it has no affinity for the insulin receptor. Although many physiological functions of relaxin are being identified, the relaxin receptor has only recently been characterized at the mole- 
cular level [13]. The most completely characterized functions for relaxin are in pregnancy, where it inhibits uterine contraction, induces softening of the birth canal, and induces lengthening of the interpubic ligament, largely by inducing extracellular matrix (ECM) remodeling (see [12] for review). Further studies have suggested that relaxin may also act as an antifibrotic agent in a number of tissues. Treatment with relaxin restored the normal phenotype after experimentally-induced fibrosis in mouse lung [14] and in rat kidney [15]. Similar results were found in two other fibrosis models, capsule formation around implanted osmotic pumps and polyvinyl alcohol sponges [16]. In clinical trials in humans, relaxin was shown to have some beneficial effects on patients suffering from scleroderma, a condition characterized by excessive fibrosis of skin and vascular tissues [17]. Recently, relaxin-null mice were found to develop pulmonary fibrosis with aging, suggesting that relaxin functions as a protective agent against fibrosis [18]. Consistent with its mechanism of action in pregnancy, the antifibrotic actions of relaxin are based on extracellular matrix remodeling. In lung and dermal fibroblasts, relaxin was shown to decrease TGF$\beta$-induced collagen type I secretion, increase MMP-1 expression, and decrease expression of a TIMP $[14,19]$. In dermal fibroblasts studies, relaxin increased collagenase expression and decreased TGF- $\beta$-induced collagen synthesis. Interestingly, in studies using scleroderma fibroblasts, relaxin inhibited collagen synthesis in the absence of TGF$\beta$ [20]. Since these cells, like activated HSC, produce elevated levels of collagen, this finding raises the possibility that relaxin may reverse the disease phenotype.

In light of the studies detailed above, relaxin appears to act as an antifibrotic agent primarily by inhibiting type I collagen deposition and promoting matrix degradation. These qualities are ideal for a fibrosis-reversing agent. Indeed, there had been speculation that relaxin might be effective as a hepatic antifibrotic agent $[1,21,22]$. A recent study reported that relaxin reduced total collagen, TIMP-1, and TIMP- 2 expression in HSC, and reduced total collagen in fibrotic rats treated with relaxin [23]. In this study, we confirm that relaxin reduces total collagen in cultured HSC, and furthermore show evidence that relaxin increases collagenase activity, decreases SMA levels, and specifically decreases type I collagen production by HSC.

\section{Materials and methods}

\subsection{Cell culture}

Rat HSC were isolated from SAS Sprague-Dawley rats (300-350 g) using sequential perfusion with pronase and collagenase, followed by density gradient centrifugation in Larcoll [24]. Cell viability was monitored by trypan blue exclusion, and HSC identified by their typical morphology and the presence of fat droplets under UV illumination. The
HSC were maintained in DMEM/Ham's F12 medium supplemented with $10 \%$ fetal bovine serum, $2 \mathrm{mM}$ glutamine, $100 \mathrm{U} / \mathrm{mL}$ penicillin and $100 \mu \mathrm{g} / \mathrm{mL}$ streptomycin at $37^{\circ}$ in a humidified $5 \% \mathrm{CO}_{2}$ atmosphere. The medium was changed $24 \mathrm{hr}$ after seeding and every $48 \mathrm{hr}$ thereafter. Within 7-10 days, the HSC displayed the activated (myofibroblastic) phenotype identified by the loss of lipid droplets and the expression of SMA by Western blot (see below). At confluence, the cells were suspended using trypsin/EDTA and subcultured. All cells were used between passages 5 and 20, since after this point they gradually lost their relaxin sensitivity. Purified porcine relaxin was obtained from A.F. Parlow and the National Hormone \& Peptide Program. Cells were treated with relaxin (0.01-100 $\mathrm{nM}$ ) for $24-48 \mathrm{hr}$ as indicated below.

\subsection{Measurement of total collagen content}

Total collagen levels were determined by a modification of the method of Jimenez et al. [25], which allows simultaneous determination of collagen and total protein by the differential binding of Sirius Red and Fast Green FCF, respectively. Briefly, subconfluent HSC in 24-well plates were treated with relaxin for $48 \mathrm{hr}$ in the presence of serum. The cells were fixed briefly with $4 \%$ buffered formalin, and then stained for 15 min with $0.01 \%$ Fast Green FCF in $0.5 \%$ picric acid. After washing, the cells were stained with $0.04 \%$ Fast Green FCF and 0.1\% Sirius Red (Direct Red 80 ) in $0.5 \%$ picric acid for $15 \mathrm{~min}$. After washing, the bound dye was solubilized in $50 \mathrm{mM} \mathrm{NaOH}$ in $50 \%$ methanol, and absorbance determined at 540 and $630 \mathrm{~nm}$ to determine Sirius Red and Fast Green FCF binding, respectively.

\subsection{Determination of type I collagen}

HSC in 24-well plates were treated with relaxin in serum-free medium containing $0.1 \%$ BSA, $50 \mu \mathrm{g} / \mathrm{mL}$ ascorbate and $80 \mu \mathrm{g} / \mathrm{mL}$ aminopropionitrile for $24 \mathrm{hr}$, and the conditioned medium collected. The treatment was limited to $24 \mathrm{hr}$ to minimize the duration of serumfree conditions in the cultures. The level of type I collagen was determined by an ELISA procedure [26]. Briefly, 96well plates were coated with conditioned media from relaxin-treated cells, then probed with rabbit anticollagen I antibody (Biodesign Intl.) followed by an alkaline phosphatase-conjugated goat antirabbit IgG. Color development was performed using $p$-nitrophenyl phosphate, and the absorbance read at $405 \mathrm{~nm}$. Purified rat tail collagen I (Sigma) was used as the standard.

\subsection{Determination of collagen synthesis rate}

The effect of relaxin on the rate of collagen synthesis was determined by the incorporation of ${ }^{3} \mathrm{H}$-proline into collagenase-digestible proteins essentially as described [27]. Briefly, HSC in 24-well plates were treated with relaxin for 
$24 \mathrm{hr}$, then the medium changed to $0.5 \mathrm{~mL}$ per well fresh medium containing $10 \%$ FBS, relaxin, $1 \mu \mathrm{Ci} / \mathrm{mL}$ L-[2,3,4,5$\left.{ }^{3} \mathrm{H}\right]$-proline (American Radiolabeled Chemicals), $50 \mu \mathrm{g} /$ $\mathrm{mL}$ ascorbate and $80 \mu \mathrm{g} / \mathrm{mL}$ aminopropionitrile for $24 \mathrm{hr}$, then the conditioned media were collected. For determination of noncollagen protein, $200 \mu \mathrm{L}$ aliquots were incubated for $3 \mathrm{hr}$ with $10 \mathrm{U} / \mathrm{mL}$ purified collagenase III (Advanced Biofactures) in $33 \mathrm{mM}$ Tris, $\mathrm{pH} 7.5$, containing $50 \mathrm{mM}$ $\mathrm{CaCl}_{2}$ and $5 \mathrm{mM}$ NEM (300 $\mu \mathrm{L}$ total volume). Proteins were precipitated by the addition of $20 \mu \mathrm{L} 10 \%$ BSA and $75 \mu \mathrm{L}$ of $50 \%$ TCA $/ 0.75 \%$ tannic acid. After $30 \mathrm{~min}$ on ice, the samples were centrifuged, and the supernatants discarded. The pellets were washed with ice-cold $10 \%$ TCA, dissolved in $1 \mathrm{~N} \mathrm{NaOH}$, and counted. Total protein synthesis was determined by processing $200 \mu \mathrm{L}$ aliquots of conditioned media as above without incubation with collagenase. Collagen synthesis was calculated as collagen protein produced as a percent of total protein in $24 \mathrm{hr}$.

\subsection{Detection of MMP activity by substrate zymography}

The gelatin and collagen-degrading activities of MMPs in HSC conditioned media were assessed by gelatin or collagen substrate zymography $[28,29]$. Cultures of HSC were treated with relaxin for $48 \mathrm{hr}$ in the presence of serum, the conditioned medium collected, diluted 1:3 in nonreducing SDS-PAGE sample buffer without heating, then resolved on a $10 \%$ polyacrylamide gel containing either $0.1 \%$ gelatin or $0.05 \%$ collagen I. After removal of SDS by immersion in $2.5 \%(\mathrm{v} / \mathrm{v})$ Triton X-100 over $30 \mathrm{~min}$, the gels were placed in incubation buffer (50 mM Tris, $\mathrm{pH} 8.0,200 \mathrm{mM} \mathrm{NaCl}, 5 \mathrm{mM} \mathrm{CaCl} 2$, $0.06 \%$ Brij-35) for $18-24 \mathrm{hr}$ at $37^{\circ}$. After staining with $0.2 \%$ Coomassie Blue R-250, the amount of MMP activity was quantified by densitometry.

\subsection{Western blotting}

HSC in 6-well plates were treated with relaxin for $48 \mathrm{hr}$ in the presence of serum, washed with ice-cold PBS, then lysed in $100 \mu \mathrm{L}$ per well lysis buffer (50 mM Tris, $\mathrm{pH} 7.4$, containing $0.15 \mathrm{M} \mathrm{NaCl}, 1.0 \%$ Triton X-100, and $0.1 \mathrm{mM}$ phenylmethylsulfonyl fluoride). Protein content in the lysates was determined using the bicinchoninic acid assay (Pierce). Equal amounts of protein $(10 \mu \mathrm{g})$ were resolved on $10 \%$ SDS-PAGE gels and then transferred to PVDF membranes. Membranes were probed with an anti-SMA monoclonal antibody (Sigma) at 1:2000 dilution, followed by a secondary horseradish peroxidase-conjugated goat antimouse antibody (Jackson Immunochemicals), and detection by enhanced chemiluminescence. The levels of SMA in cell lysates were quantified by densitometry. As a loading control, membranes were stripped and reprobed for the presence of $\alpha$-tubulin using a monoclonal antibody (Sigma). For detection of secreted proteins, conditioned media from activated HSC was collected $48 \mathrm{hr}$ after treat- ment without and with $10 \mathrm{nM}$ relaxin, and were passed through a Cibracon blue column (Pierce) to remove albumin. Samples were concentrated 5-fold using a Centricon10 microconcentrator (Amicon) and resolved on either 12 or $10 \%$ SDS-PAGE. Immunoblotting for was performed using monoclonal antibodies specific for TIMP-2 (Calbiochem) and MMP-13 (Chemicon) or a polyclonal antibody for TIMP-1 (Santa Cruz Biotechnology).

\subsection{RT-PCR for detection of MMP-13 mRNA}

Total RNA was extracted from activated HSC after treatment without and with relaxin $(100 \mathrm{nM})$ using Trizol (Invitrogen) according to the manufacturer's instructions. Genomic DNA was removed by DNase treatment, and cDNA was generated using a cloned AMV reverse transcriptase kit (Invitrogen). Samples were analyzed by PCR for MMP-13 expression using the primers and PCR program described previously [30], or for glyceraldehyde 3phosphate dehydrogenase (GAPDH) using a primer set (Clontech). Samples were resolved on agarose gels and products detected by ethidium bromide staining.

\subsection{Cell proliferation assay}

The effect of relaxin on the rate of cell growth was determined by the incorporation of radiolabeled thymidine. Subconfluent cultures of HSC in 24-well plates were treated with relaxin for $48 \mathrm{hr}$ in the presence of serum. For the final $4 \mathrm{hr}$ of treatment, cells received $0.1 \mu \mathrm{Ci} / \mathrm{mL}$ [6${ }^{3} \mathrm{H}$-thymidine (Amersham). After the labeling period, the cells were washed three times with PBS, then treated with $0.25 \mathrm{~mL} 10 \%$ trichloroacetic acid (TCA) to precipitate the DNA. The supernatants were removed, and the wells washed with $2 \%$ TCA. The precipitate was solubilized in $0.25 \mathrm{~mL} 0.1 \mathrm{M} \mathrm{NaOH} 0.1 \%$ SDS solution, and counted. Data are expressed as the percent incorporation of thymidine compared to untreated cells.

\subsection{Statistics}

All data are expressed as mean \pm SE. Comparisons for differences between groups were made by ANOVA with Tukey's post-test. $P<0.05$ was interpreted as significant. Curve-fitting was performed using GraphPad Prism 3.0 software package.

\section{Results}

When HSC are grown on plastic, they display the activated phenotype within 7-10 days, characterized by expression of SMA. Relaxin treatment of HSC for $48 \mathrm{hr}$ decreased SMA levels as detected by Western blotting in a dose-dependent manner (Fig. 1). The inhibition of SMA level was detectable at $0.1 \mathrm{nM}$ relaxin, and a maximum 
(A)
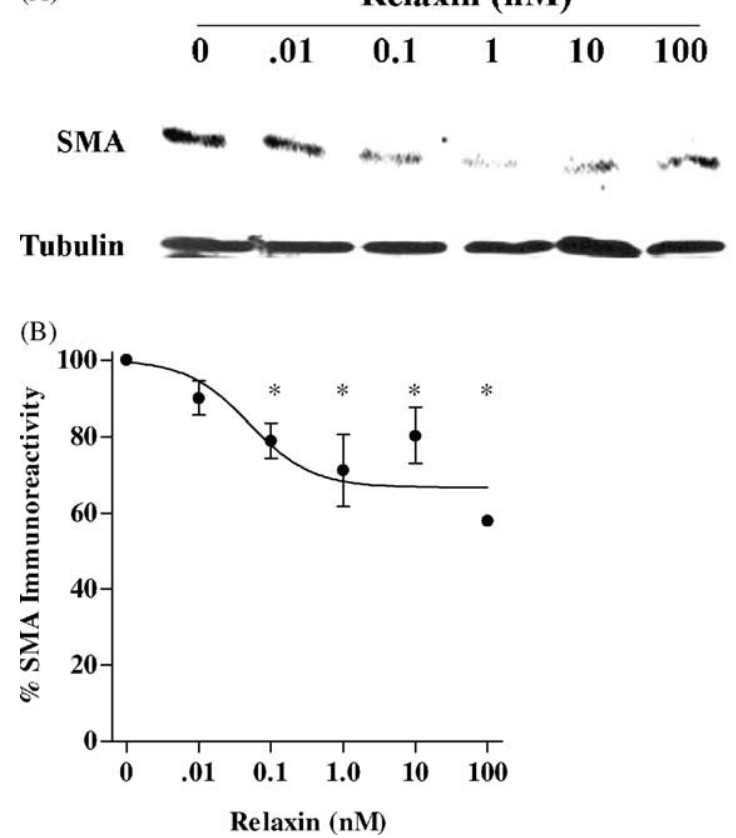

Fig. 1. Relaxin decreases SMA levels in HSC. (A) Lysates were prepared from HSCs treated with the indicated concentrations of relaxin for $48 \mathrm{hr}$. The presence of smooth muscle $\alpha$-actin (SMA) was detected by Western blotting. As a loading control, blots were stripped and reprobed for $\alpha$-tubulin. (B) The SMA content in cell lysates was quantified by densitometry. Data are expressed as percent of SMA present without relaxin (mean $\pm \mathrm{SE}, \mathrm{N}=3,{ }^{*} P<0.05$ ).

decrease of approximately $40 \%$ was seen at $1 \mathrm{nM}$ relaxin. No obvious morphological changes in the cells were observed after relaxin treatment. To explore the possibility that decreased SMA was due to decreased cell proliferation, relaxin-treated cells were metabolically labeled with ${ }^{3} \mathrm{H}$-thymidine, and the rate of thymidine incorporation into DNA determined. Relaxin treatment had no significant effect on the cell proliferation rate (Fig. 2). Thus, the

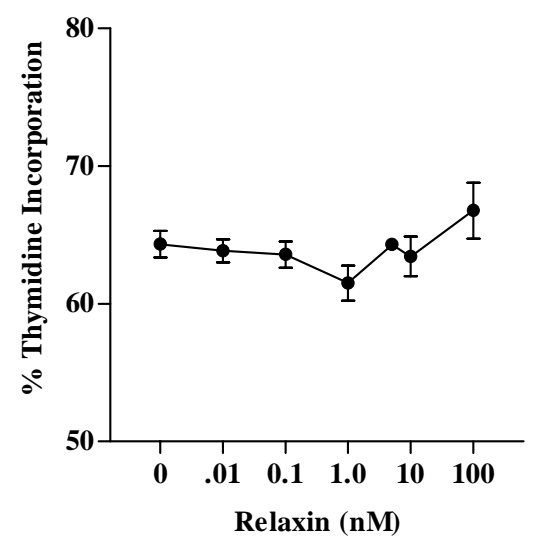

Fig. 2. The effect of relaxin on DNA synthesis by HSC. HSC cultures were treated with relaxin for $48 \mathrm{hr}$. For the final $18 \mathrm{hr}$, cells were metabolically labeled with ${ }^{3} \mathrm{H}$-thymidine. The DNA was solubilized and counted. Data are expressed as the percent incorporation of ${ }^{3} \mathrm{H}$-thymidine compared to untreated cells (mean $\pm \mathrm{SE}, \mathrm{N}=3$ ).

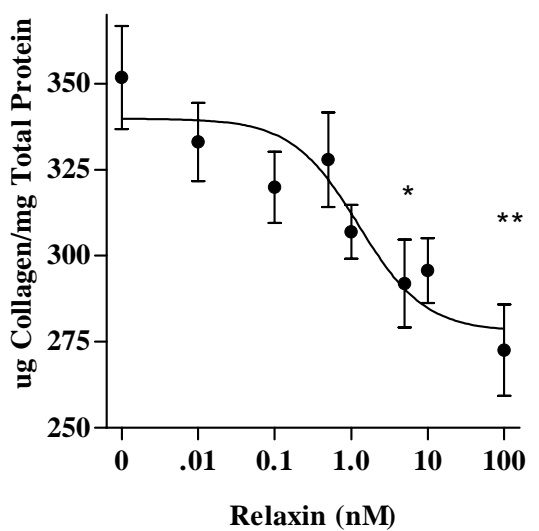

Fig. 3. Relaxin decreases HSC total collagen content. HSC were treated with relaxin for $48 \mathrm{hr}$ then fixed in formalin. The collagen content was then measured by differential staining with Sirius Red and Fast Green FCF. Data are expressed as $\mu \mathrm{g}$ collagen per mg total protein (mean $\pm \mathrm{SE}, \mathrm{N}=3$, $\left.{ }^{*} P<0.05,{ }^{* *} P<0.01\right)$.

inhibitory effect of relaxin on SMA levels was not due to inhibition of the cellular growth rate.

Activation of HSC is also characterized by an elevation in collagen levels. The effect of relaxin on the level of total collagen by HSC was determined by Sirius Red/Fast Green FCF staining. Relaxin treatment for $48 \mathrm{hr}$ induced a dose-dependent reduction in total collagen content as a function of total protein (Fig. 3). The maximal decrease achieved was approximately $30 \%$. The half-maximal inhibitory dose of relaxin was $1.2 \mathrm{nM}$, consistent with the action of relaxin through its receptor [13]. To determine if relaxin influences the rate of new collagen synthesis in HSC, cells were treated with relaxin for $48 \mathrm{hr}$, and were metabolically labeled with ${ }^{3} \mathrm{H}$-proline for the final $24 \mathrm{hr}$. The collagen production was determined by the amount of collagenase-sensitive radiolabeled protein. Relaxin treatment caused a dose-dependent decrease in the rate of collagen synthesis (Fig. 4), suggesting that the reduction

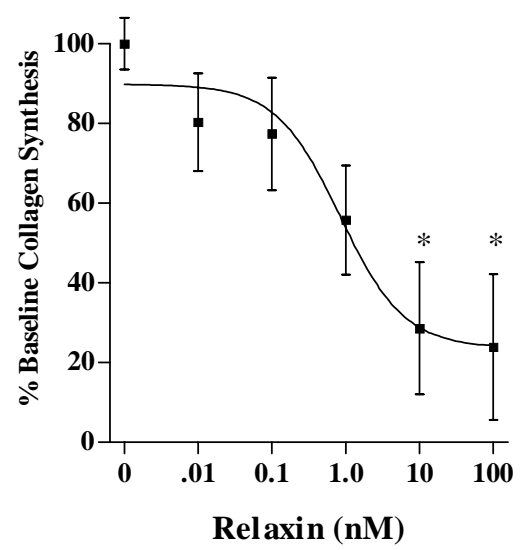

Fig. 4. Relaxin decreases collagen synthesis by HSC. HSC cultures were metabolically labeled with ${ }^{3} \mathrm{H}$-proline for $24 \mathrm{hr}$ in the presence of relaxin, ascorbate and aminopropionitrile. Proteins were incubated without and with bacterial collagenase. Data are expressed as the percent collagensensitive radiolabeled material compared with untreated cells (mean $\pm \mathrm{SE}$, $\left.\mathrm{N}=3,{ }^{*} P<0.05\right)$. 


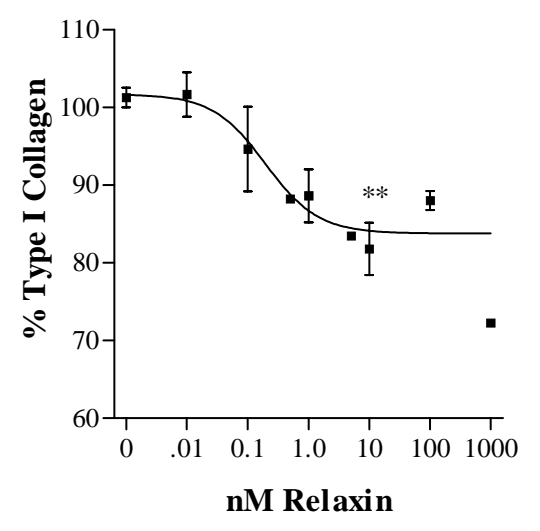

Fig. 5. Relaxin decreases type I collagen levels. HSC cultures were treated with relaxin for $24 \mathrm{hr}$ in serum-free medium in the presence of ascorbate and aminopropionitrile. The conditioned medium was collected and analyzed for type I collagen content by ELISA. Data are expressed as percent of type I collagen content in untreated cells (mean $\pm \mathrm{SE}, \mathrm{N}=4$, ${ }^{* *} P<0.01$ ). The actual baseline collagen I concentrations ranged from 38 to $54 \mu \mathrm{g} / \mathrm{mL}$.

in total collagen is due at least in part to a decrease in overall collagen synthesis.

While the level of total collagen increases with HSC activation, a qualitative shift also occurs, resulting in an increase in interstitial (e.g. type I) over the basement membrane-type collagens. Therefore, the effect of relaxin on type I collagen production by HSC was specifically determined

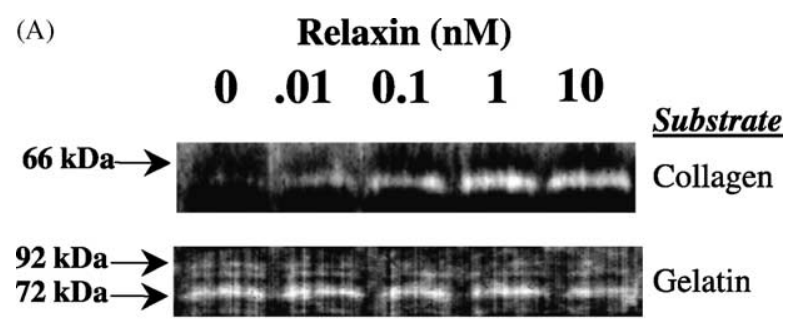

(B)

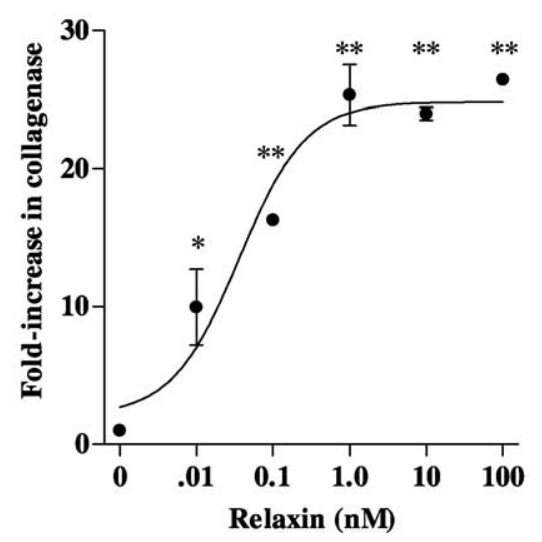

Fig. 6. Relaxin effect on collagenase and gelatinase activity in HSC cultures. (A) Conditioned media were collected from HSCs treated with relaxin for $48 \mathrm{hr}$. The media were subjected to collagen I (top panel) or gelatin (bottom panel) substrate zymography under nonreducing conditions. (B) The band of collagenase activity migrating at $\sim 60 \mathrm{kDa}$ was quantified by densitometry. Data are expressed as fold-increase in collagenase activity over baseline (mean $\pm \mathrm{SE}, \mathrm{N}=3,{ }^{*} P<0.05,{ }^{* *} P<0.01$ ). by ELISA. Relaxin treatment for $24 \mathrm{hr}$ resulted in a $20 \%$ maximal decrease in the level of type I collagen in cultured HSC (Fig. 5). As in the above experiments, the effect was dose-dependent and the effective dose was consistent with action through the relaxin receptor. Thus, relaxin decreased the production of a fibrillar collagen by activated HSC.

Collagen levels are regulated not only by synthesis and secretion, but also by degradation by the matrix metalloproteinases (MMPs). Activation of HSC is characterized by decreased production of interstitial collagenase [7]. The effect of relaxin on collagen-degrading MMP activities was examined by collagen substrate zymography (Fig. 6). In the absence of relaxin, there were no collagen-degrading MMPs detectable other than those present in serum. Relaxin treatment resulted in a dramatic increase in a band migrating at approximately $60 \mathrm{kDa}$, consistent with the migration of rat pro-MMP-13, the rodent interstitial collagenase [31]. When the data were quantified by densitometry, relaxin treatment caused a dose-dependent increase in the collagenase, with a maximal 25 -fold increase at $1 \mathrm{nM}$. Thus, relaxin treatment induced an increase in collagenase, which may contribute to the decrease in overall collagen content. Similar experiments were performed using gelatin substrate zymography, which predominantly measures the activity of the $72 \mathrm{kDa}$ gelatinase $\mathrm{A}$

(A)

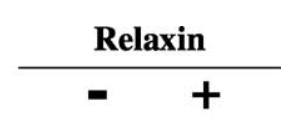

MMP-13

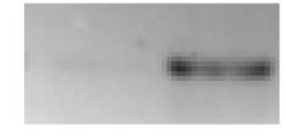

GAPDH

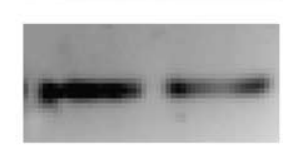

(B)

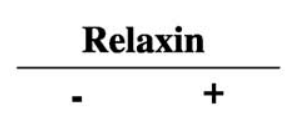

MMP-13

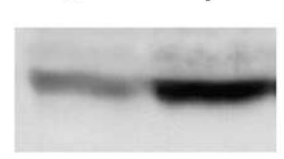

TIMP-1

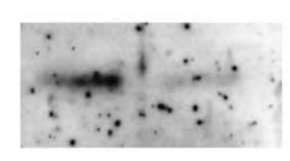

TIMP-2

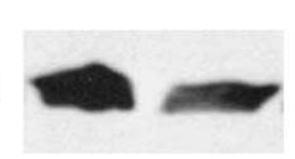

Fig. 7. Relaxin effect on expression of MMP-13 and secretion of MMP-13 and TIMPs. (A) Total RNA from HSC treated without $(-)$ and with $(+)$ $100 \mathrm{nM}$ relaxin was analyzed by RT-PCR for expression of MMP-13 or GAPDH as described in Section 2. The colors of the figure are inverted for easier viewing. (B) 48-hr conditioned medium from HSC treated without $(-)$ and with $(+) 10 \mathrm{nM}$ relaxin was analyzed by Western blotting for MMP-13, TIMP-1 or TIMP-2 as described in Section 2. 
(MMP-2) and the $92 \mathrm{kDa}$ gelatinase B (MMP-9). Relaxin treatment had no effect on the activity of these gelatinases.

To determine more directly if the collagenase activity detected above was due to MMP-13 expression, total RNA from treated and untreated HSC were analyzed by RT-PCR (Fig. 7A). In the absence of relaxin, expression of MMP-13 was virtually undetectable. Relaxin treatment resulted in a clear increase in MMP-13 expression. To analyze the secretion of MMP-13, conditioned media from HSC treated without and with relaxin was analyzed by Western blotting (Fig. 7B). In the absence of relaxin, a very low level of MMP-13 was detected, while relaxin treatment caused an increase in MMP-13. In the same samples, the secretion of TIMP-1 was markedly decreased with relaxin treatment, while TIMP-2 secretion was decreased modestly.

\section{Discussion}

The successful treatment of hepatic fibrosis hinges on the removal of damaging excess extracellular matrix. Since activated HSC play a major role in the production of collagen, agents that reduce or reverse the activated phenotype are prime candidates for therapeutic agents. Relaxin has demonstrated antifibrotic action in a number of cells and tissues, including lung, skin, and kidney [1416], and recently liver [23]. These effects appear to be due at least in part to effects on fibroblasts, and include reduced ECM production and increased matrix degradation. Because HSC are the matrix-producing fibroblastic cell type involved in hepatic fibrosis, we sought to determine the effect of relaxin on activated HSC.

Relaxin was shown to reduce the level of SMA, a marker of HSC activation. The increased expression of SMA is postulated to contribute to HSC contractility, a process involved in portal hypertension [4]. Therefore, relaxin treatment may also be of benefit in the treatment of portal hypertension. The decrease in SMA was not due to impaired cell proliferation, as relaxin had no effect on DNA synthesis by HSC. The activation of HSC is also accompanied by elevated collagen secretion. With relaxin treatment of HSC, the total collagen content, collagen synthesis, and type I collagen levels were decreased. Thus, relaxin inhibited the primary element responsible for the production of fibrillar matrix in liver injury. Since the level of SMA in the cells was also decreased, relaxin may be acting to reverse HSC activation and to restore the quiescent phenotype.

While a reduction in collagen production is beneficial, the removal of fibrillar collagen is necessary for the repair of hepatic fibrosis. In the recovery stage of experimental hepatic fibrosis, a large induction of MMP-13 expression was detected [30], suggesting that MMP-13 is an integral part of the antifibrotic process. In HSC cultures, relaxin increased the expression and secretion of MMP-13. At the same time, the secretion of TIMP-1 and TIMP-2 was decreased, consistent with an earlier report [23]. The reduction in TIMP levels would result in elevated MMP activity. Therefore, relaxin acts on HSC in a two-pronged manner, first by reducing HSC markers of HSC activation (reduced the production of collagen and SMA by HSC), and second by promoting fibrillar matrix degradation by elevating collagenase activity. The result is a shift in the HSC from a phenotype that contributes to fibrosis to one that promotes recovery.

The results demonstrating relaxin reduction of total collagen content and collagen synthesis are in good agreement with the results of a recently published study examining relaxin effects on HSC cultures [23]. However, that study detected no effect of relaxin on the expression of SMA, type I collagen, or MMP-13 mRNA as determined by Northern blotting. This raises the possibility that the changes in some of these proteins may not be reflected at the transcriptional level, although we were able to detect increased MMP-13 by a different technique (RT-PCR). Alternatively, it may be possible that the different sources of relaxin (recombinant human relaxin vs. the purified native porcine used in this study) may have variable effects on rat HSC. Indeed, there is only 40-70\% homology of relaxin sequences across species [12], and relaxins from different species have demonstrated variable effects in tissues [32].

The effective concentration of relaxin required for all effects was consistent with action through the newly identified relaxin receptors LGR7 and LGR8 [13]. Of these, LGR7 expression was detected in whole liver mRNA. Interestingly, unlike insulin receptors, relaxin receptors are both 7-transmembrane spanning, G-protein-coupled receptors, which act via a pathway involving cAMP. It is interesting to note that an increase in the levels of cAMP in HSC decrease some markers of HSC activation [33-35]. Therefore, the mechanism of action of relaxin in stellate cells is likely through one or both of the relaxin receptors through elevation of cAMP. Preliminary studies have suggested that activated HSC express LGR7 and possibly LGR8 as well (data not shown). Studies are currently underway to characterize the relaxin receptors in HSC, and to determine the signaling properties of relaxin.

There is considerable evidence that liver fibrosis is a reversible condition. In a number of clinical situations, such as autoimmune disease and hepatitis B and C after successful treatment, a restoration to nearly normal cell architecture was observed, suggesting that the mechanisms exist to clear tissue scarring (reviewed in [36]). This concept has been supported in experimental animal models of liver fibrosis. In $\mathrm{CCl}_{4}$-induced fibrosis after $\mathrm{CCl}_{4}$ withdrawal, and in the bile duct ligation model after bilioduodenal anastomosis, liver architecture was returned to nearly normal [30,37-39]. The recovery phase is accompanied by a change in the ECM remodeling to favor the restoration of the basement membrane-type ECM. Contributing to the resolution of fibrosis is a decrease in collagen expression 
[37,38]. In addition, an increased in interstitial collagenase expression as well as decreased in TIMP expression were seen during the recovery stage $[30,37]$. The ultimate result is that the balance between deposition and degradation of collagen I was restored to a collagen I-degrading environment. It is still unclear what mechanisms may be involved in the "inactivation" of HSC, but there is evidence that apoptosis of activated HSCs may be involved in recovery from experimentally-induced fibrosis [37]. Alternatively, some reports have shown evidence that activated HSCs may revert to a quiescent phenotype. Treatment of culture-activated HSC with interferon- $\gamma$ decreased markers of HSC activation, including proliferation and the expression of collagen and SMA [40]. Other studies showed that ligands of peroxisome proliferator-activated receptor- $\gamma$ resulted in a decreased collagen synthesis and SMA expression, and a simultaneous increase in MMP-13 expression, with no evidence of apoptosis [41,42]. Finally, a recent study demonstrated reversion of activated HSC to a quiescent phenotype by growth on basement membrane substratum [43]. These findings suggest that reversal of HSC activation is possible, and thus an attractive target for fibrosis treatment. In the present study, relaxin inhibited myofibroblastic properties of HSC, but had no effect on cell proliferation, and moreover stimulated secretion of collagenase. Therefore, it seems likely that relaxin acts to reverse HSC activation rather than by the induction of apoptosis. In conclusion, the studies presented here suggest that a candidate agent for reversal of HSC activation and possible therapeutic treatment of hepatic fibrosis is the hormone relaxin.

\section{Acknowledgments}

This work was supported by funding from the Department of Veterans Affairs (R.G.B., D.J.T., K.K.K.), and the Bly Memorial Research Fund (R.G.B.).

\section{References}

[1] Li D, Friedman SL. Liver fibrogenesis and the role of hepatic stellate cells: new insights and prospects for therapy. J Gastroenterol Hepatol 1999;14:618-33.

[2] McCrudden R, Iredale JP. Liver fibrosis, the hepatic stellate cell and tissue inhibitors of metalloproteinases. Histol Histopathol 2000;15: 1159-68.

[3] Friedman SL. Molecular regulation of hepatic fibrosis, an integrated cellular response to tissue injury. J Biol Chem 2000;275:2247-50.

[4] Rockey DC, Housset CN, Friedman SL. Activation-dependent contractility of rat hepatic lipocytes in culture and in vivo. J Clin Invest 1993;92:1795-804.

[5] Rockey DC, Boyles JK, Gabbiani G, Friedman SL. Rat hepatic lipocytes express smooth muscle actin upon activation in vivo and in culture. J Submicrosc Cytol Pathol 1992;24:193-203.

[6] Geerts A, Vrijsen R, Rauterberg J, Burt A, Schellinck P, Wisse E. In vitro differentiation of fat-storing cells parallels marked increase of collagen synthesis and secretion. J Hepatol 1989;9:59-68.
[7] Iredale JP, Benyon RC, Arthur MJ, Ferris WF, Alcolado R, Winwood PJ, Clark N, Murphy G. Tissue inhibitor of metalloproteinase-1 messenger RNA expression is enhanced relative to interstitial collagenase messenger RNA in experimental liver injury and fibrosis. Hepatology 1996;24:176-84.

[8] Benyon RC, Hovell CJ, Da Gaca M, Jones EH, Iredale JP, Arthur MJ. Progelatinase A is produced and activated by rat hepatic stellate cells and promotes their proliferation. Hepatology 1999;30:977-86.

[9] Theret N, Lehti K, Musso O, Clement B. MMP2 activation by collagen I and concanavalin A in cultured human hepatic stellate cells. Hepatology 1999;30:462-8.

[10] Iredale JP, Murphy G, Hembry RM, Friedman SL, Arthur MJ. Human hepatic lipocytes synthesize tissue inhibitor of metalloproteinases-1. Implications for regulation of matrix degradation in liver. J Clin Invest 1992;90:282-7.

[11] Bani D. Relaxin: a pleiotropic hormone. Gen Pharmacol 1997;28: 13-22.

[12] Bryant-Greenwood GD, Schwabe C. Human relaxins: chemistry and biology. Endocrinol Rev 1994;15:5-26.

[13] Hsu SY, Nakabayashi K, Nishi S, Kumagai J, Kudo M, Sherwood OD, Hseuh AJW. Activation of orphan receptors by the hormone relaxin. Science 2002;295:671-4.

[14] Unemori EN, Pickford LB, Salles AL, Piercy CE, Grove BH, Erikson ME, Amento EP. Relaxin induces an extracellular matrix-degrading phenotype in human lung fibroblasts in vitro and inhibits lung fibrosis in a murine model in vivo. J Clin Invest 1996;98:2739-45.

[15] Garber SL, Mirochnik Y, Brecklin CS, Unemori EN, Singh AK, Slobodskoy L, Grove BH, Arruda JA, Dunea G. Relaxin decreases renal interstitial fibrosis and slows progression of renal disease. Kidney Int 2001;59:876-82.

[16] Unemori EN, Beck LS, Lee WP, Xu Y, Siegel M, Keller G, Liggitt HD, Bauer EA, Amento EP. Human relaxin decreases collagen accumulation in vivo in two rodent models of fibrosis. J Invest Dermatol 1993;101:280-5.

[17] Seibold JR, Korn JH, Simms R, Clements PJ, Moreland LW, Mayes MD, Furst DE, Rothfield N, Steen V, Weisman M, Collier D, Wigley FM, Merkel PA, Csuka ME, Hsu V, Rocco S, Erikson M, Hannigan J, Harkonen WS, Sanders ME. Recombinant human relaxin in the treatment of scleroderma. A randomized, double-blind, placebo-controlled trial. Ann Intern Med 2000;132:871-9.

[18] Samuel CS, Zhao C, Bathgate RA, Bond CP, Burton MD, Parry LJ, Summers RJ, Tang ML, Amento EP, Tregear GW. Relaxin deficiency in mice is associated with an age-related progression of pulmonary fibrosis. FASEB J 2003;17:121-3.

[19] Unemori EN, Amento EP. Relaxin modulates synthesis and secretion of procollagenase and collagen by human dermal fibroblasts. J Biol Chem 1990;265:10681-5.

[20] Unemori EN, Bauer EA, Amento EP. Relaxin alone and in conjunction with interferon-gamma decreases collagen synthesis by cultured human scleroderma fibroblasts. J Invest Dermatol 1992;99:337-42.

[21] Friedman SL. Hepatic fibrosis. In: Schiff ER, Sorrell MF, Maddrey WC, editors. Schiff's diseases of the liver. Philadelphia: LippincottRaven; 1999. p. 371-85.

[22] Schuppan D, Atkinson J, Ruehl M, Riecken EO. Alcohol and liver fibrosis-pathobiology and treatment. Z Gastroenterol 1995;33: 546-50.

[23] Williams EJ, Benyon RC, Trim N, Grove BH, Arthur MJ, Unemori EN, Iredale JP. Relaxin inhibits effective collagen deposition by cultured hepatic stellate cells and decreases rat liver fibrosis in vivo. Gut 2001;49:577-83.

[24] Friedman SL, Roll FJ. Isolation and culture of hepatic lipocytes, Kupffer cells, and sinusoidal endothelial cells by density gradient centrifugation with Stractan. Anal Biochem 1987;161:207-18.

[25] Jimenez W, Pares A, Caballeria J, Heredia D, Bruguera M, Torres M, Rojkind M, Rodes J. Measurement of fibrosis in needle liver biopsies: evaluation of a colorimetric method. Hepatology 1985;5:815-8. 
[26] Moshage H, Casini A, Lieber CS. Acetaldehyde selectively stimulates collagen production in cultured rat liver fat-storing cells but not hepatocytes. Hepatology 1990;12:511-8.

[27] Postlethwaite AE, Smith GN, Mainardi CL, Seyer JM, Kang AH. Lymphocyte modulation of fibroblast function in vitro: stimulation and inhibition of collagen production by different effector molecules. $\mathbf{J}$ Immunol 1984;132:2470-7.

[28] Heussen C, Dowle EB. Electrophoretic analysis of plasminogen activators in polyacrylamide gels containing sodium dodecyl sulfate and copolymerized substrates. Anal Biochem 1980;102:196-202.

[29] Gogly B, Groult N, Hornebeck W, Godeau G, Pellat B. Collagen zymography as a sensitive and specific technique for the determination of subpicogram levels of interstitial collagenase. Anal Biochem 1998;255:211-6.

[30] Watanabe T, Niioka M, Hozawa S, Kameyama K, Hayashi T, Arai M, Ishikawa A, Maruyama K, Okazaki I. Gene expression of interstitial collagenase in both progressive and recovery phase of rat liver fibrosis induced by carbon tetrachloride. J Hepatol 2000;33:224-35.

[31] Quinn CO, Scott DK, Brinckerhoff CE, Matrisian LM, Jeffrey JJ, Partridge NC. Rat collagenase. Cloning, amino acid sequence comparison, and parathyroid hormone regulation in osteoblastic cells. J Biol Chem 1990;265:22342-7.

[32] Schwabe C, Bullesbach EE. Relaxin: structures, functions, promises, and nonevolution. FASEB J 1994;8:1152-60.

[33] Mallat A, Preaux AM, Serradeil-Le Gal C, Raufaste D, Gallois C, Brenner DA, Bradham C, Maclouf J, Iourgenko V, Fouassier L, Dhumeaux D, Mavier P, Lotersztajn S. Growth inhibitory properties of endothelin-1 in activated human hepatic stellate cells: a cyclic adenosine monophosphate-mediated pathway. Inhibition of both extracellular signal-regulated kinase and c-Jun kinase and upregulation of endothelin B receptors. J Clin Invest 1996;98:2771-8.

[34] Kawada N, Kuroki T, Kobayashi K, Inoue M, Kaneda K. Inhibition of myofibroblastic transformation of cultured rat hepatic stellate cells by methylxanthines and dibutyryl cAMP. Dig Dis Sci 1996;41:1022-9.
[35] Reinehr R, Fischer R, Haussinger D. Regulation of endothelin: a receptor sensitivity by cyclic adenosine monophosphate in rat hepatic stellate cells. Hepatology 2002;36:861-73.

[36] Benyon RC, Iredale JP. Is liver fibrosis reversible? Gut 2000;46: 443-6.

[37] Iredale JP, Benyon RC, Pickering J, McCullen M, Northrop M, Pawley S, Hovell C, Arthur MJ. Mechanisms of spontaneous resolution of rat liver fibrosis. Hepatic stellate cell apoptosis and reduced hepatic expression of metalloproteinase inhibitors. J Clin Invest 1998;102: 538-49.

[38] Ramm GA, Carr SC, Bridle KR, Li L, Britton RS, Crawford DHG, Vogler CA, Bacon BR, Tracy TF. Morphology of liver repair following cholestatic liver injury: resolution of ductal hyperplasia, matrix deposition and regression of myofibroblasts. Liver 2000;20: 387-96.

[39] Issa R, Williams E, Trim N, Kendall T, Arthur MJ, Reichen J, Benyon RC, Iredale JP. Apoptosis of hepatic stellate cells: involvement in resolution of biliary fibrosis and regulation by soluble growth factors. Gut 2001;48:548-57.

[40] Rockey DC, Maher JJ, Jarnagin WR, Gabbiani G, Friedman SL. Inhibition of rat hepatic lipocyte activation in culture by interferongamma. Hepatology 1992;16:776-84.

[41] Miyahara T, Schrum L, Rippe R, Xiong S, Yee Jr HF, Motomura K, Anania FA, Willson TM, Tsukamoto H. Peroxisome proliferatoractivated receptors and hepatic stellate cell activation. J Biol Chem 2000;275:35715-22.

[42] Marra F, Efsen E, Romanelli RG, Caligiuri A, Pastacaldi S, Batignani G, Bonacchi A, Caporale R, Laffi G, Pinzani M, Gentilini P. Ligands of peroxisome proliferator-activated receptor gamma modulate profibrogenic and proinflammatory actions in hepatic stellate cells. Gastroenterology 2000;119:466-78.

[43] Sohara N, Znoyko I, Levy MT, Trojanowska M, Reuben A. Reversal of activation of human myofibroblast-like cells by culture on a basement membrane-like substrate. J Hepatol 2002;37:214-21. 